\section{Kent Uçar,}

\section{Yazı Kalır}

Sevince BAYRAK

Ístanbul Teknik Üniversitesi

Fen Bilimleri Enstitüsü,

Mimarı Tasarım Programı Doktora Öğrencisi

“Kitaplar kızlardan çok daha uzun ömürlüdür.”

Nabokov

Mimarların yapıları ile yazılarını beraber değerlendirmek çoğu zaman beklenildiği kadar verimli sonuçlanmayabilir. Bu durum biraz büyük eserler vermiş bir sanatçının gerçek hayatında katlanılamaz bir karakter olduğunu öğrenen okurun karşılaştığı hayal kırıklığına benzer. Bazen yazı büyük eser olur, yapı bir başarısızlık, bazen de tam tersi. Burada bahsi geçen yapı bir bina da olabilir, bir kent tasarımı da. Ancak bazen de, örneğin bir kitabı ve şehri birlikte değerlendirmek, kıyaslamak için değilse de, bir nevi dedektiflik yaparak yapılar ve mimarlarla ilgili yeni tartışmalar başlatmak için verimli olabilir. Bu makalenin konusu olan Almere kenti ve The Harvard Design School Guide to Shopping'i beraber okumanın da altında yatan temel sebep bu. Bu ikisi, varlık nedenleri bu olmasa da, başka ortamlarda başka ekiplerle üretilmiş olsalar da, birbirlerinin payandası gibi. Alışveriş üzerine yazılmış bir kitap, alışveriş üzerine kurulmuş bir şehir ve ikisinin ortak noktası olan bir mimar:
Rem Koolhaas. Hem kitap, hem de Almere master planı, farklı kaynaklarda çokça eleştiri ve yorum almış olmasına rağmen, bu ikisi arasında önceden planlanmış ya da rastlantısal bir ilişkiyi irdeleyen bir kaynağa rastlanmıyor. Varlığı sorgulanabilecek bu ilişki üzerine kaleme alınan bu makalede, kentsel tasarımın içinde barındırdı ̆̆ dair ipuçlarının ortaya serilmesi amaçlanıyor.

İçeriği her türlü çelişki, kararsızlık ve istenmeyenden arındırılmış bir kent planlama tavrının geçerliliğini yitirdiği bir dönemdeyiz. "Gerçek kent"in nasıl tasarlanabileceğine dair sorularla karş1 karşıya kaldığımız tartışmalarla içiçeyiz. Bütün bunlara rağmen, kent planlama eyleminin günümüzde hala geçerli olan bir kusursuzluk beklentisinden muzdarip olduğunu söyleyebiliriz. Gerçekleşmesi mümkün olmayan bir kusursuz kent ideali kent yöneticilerinin ve dolaylı olarak tasarımcıların peşini bırakmazken; formülü bir türlü çözülemeyen, sokakları canlı, "gerçek kent” de bütün gücüyle karşımızda duruyor. Gerçekliğin, kusurluluğun tasarlanamaz olduğunu
Öz

Bu çalışmada alışveriş eyleminin kentleşmedeki rolü; Almere kenti ve Harvard Design School Guide to Shopping kitabının çapraz okunması ile incelenmiştir. Aynı dönemlerde ortaya çıkan Almere master planı ve HDSGS'yi hazırlayan ekiplerin ortak noktası Rem Koolhaas'tır. Bir kent merkezinin ortaya çıkış sürecine paralel olarak, mimarların kentsel tasarımdaki tereddütleri, öz eleştirileri de bu çalışmada ele alınmış; planlama ve kentsel tasarım disiplinin bu boyutunun da makaleye dahil edilmesi amaçlanmıştır. Kuruluşu 70'li y1llara dayanan Almere'nin yeni bir kent merkezi tasarımı için 1994 yılında açtığı yarışma ile başlayan süreç ve Koolhaas'ın Harvard Design School'daki öğrencileri ile beraber hazırladığı, 2001 yılında yayımlanan kitap arasında olabileceği öngörülen bağlar incelenerek, güncel kentleşme paradigmalarına dair bir kesit ele alınır. Koolhaas ve ekibinin master plan tasarımındaki kararlarının, HDSGS'deki araştırma ve yorumlamalarla ne derece ilişkili olabileceği sorgulaması üzerinden yapılan bu çapraz okumanın, kentleşme süreçlerinin ardında yatan çok aktörlü hikayelere dair bir zemin oluşturması amaçlanır. Almere'nin geçirdiği değişimler, kent yöneticilerinin bu süreçteki rolü ve alışverişin bir kent tasarımını nasıl şekillendirebileceği çeşitli örnekler üzerinden incelenirken, mimarın bugün kentteki konumu da sorgulanır.

\section{Abstract}

In this article, the role of shopping in urbanism as an activity is investigated through Almere master plan design and Harvard Design School Guide to Shopping. Rem Koolhaas is the common actor between the city plan and the book which was published concurrently. Parallel to a city centre formation process, a story of architects' perplexity about urbanization and the self-critism which comes out due to the constructed city image is illustrated. Almere which was founded in 1970s, has experienced a radical change after the master plan design competition which OMA won the 1st prize, in 1994. After a while, Koolhaas with his students in Harvard Design School prepared Project on the City 2: Harvard Design School Guide to Shopping, and published it in 2001. In this paper, the correlation between the book and the city plan and how they contribute to current urbanization discussions, is illustrated by analyzing the role of shopping in two examples. A story of Almere's change with plural actors reveals due to this analysis which contributes the role of shopping in urban design, and the role of architect in cities today. Anahtar kelimeler:

Alışveriş, Rem Koolhaas, Almere, Harvard Design School Guide to Shopping.

Keywords:

Shopping, Rem Koolhaas, Almere, Harvard Design School Guide to Shopping. 
kabul etmek yerine kolları sıvayıp harekete geçen, "çirkinlik seven" mimar Koolhaas'ın Almere'si de bu tartışma için oldukça verimli bir altlık sunuyor. Bir kent merkezinin ortaya çıkış sürecini incelerken; mimarların kentle, kentsel tasarımla olan ilişkisine, tereddütlerine ve öz eleştirilerine dair bir hikayenin de paralel olarak devam ettiği bu makale sözü edilen tartışma üzerinden ilerliyor.

\section{Iade-i itibar}

Editörleri arasında Koolhaas'ın da bulunduğu Harvard Design School Guide to Shopping (HDSGS), 2001 y1lında yayımlandı. Çeşitli yazarlara ait makaleler ve onları destekleyen grafik ve tablo gibi görsellerden oluşan kitapta, öne çıkan tespitler şöyleydi: Modern mimarlık, yıllarca bir program olarak alışverişi küçümsemiş, yoksaymış, hor görmüştü. Konut, okul, müze gibi daha "kutsal programlar" dururken, modern mimarlığın önde gelen figürleri için alışveriş mekanları tasarlamak, portfolyolarından sakındıkları bir işti (Herman, 2001a, 391). Değil tasarlamak, üzerine yazılacak konular arasında bile son siralardayd 1 alışveriş; 1977-1997 yılları arasında yayınlanmış, içinde alışveriş merkezi $(A V M)$, dükkan, mağaza gibi alışveriş mekanları ile ilgili anahtar kelimeler geçen makalelerin toplam sayısı, içinde yalnızca "müze” sözcüğü geçenlerin alt1da biriydi (Leong, 2001, 130).

Halbuki, alışveriş hangi dönemde olursa olsun mimarlığın, kentleşmenin ve günlük hayatın aslında çok önemli bir kısmını kaplar. Pazar yerleri, pasajlar, dükkanlar, çok katlı mağazalar ve AVM'ler, alışverişin farklı dönemlerde yer aldığ 1 mekansal tipolojilerdir. HDSGS, bu tuhaf çelişkiyi gözler önüne sererek, alışverişin mimarlıkla olan ilişkisini yeniden ele alır. AVM'ler, kentin 20. yüzyılda edindiği, akademisyenler ve önde gelen tasarımcılar tarafından uzunca bir süre görmezden gelinen bir unsuru iken, HDSGS'de kapsamlı bir araştırmanın konusu olur. HDSGS, alışverişe üstten bakmaz, içine girer, her yerine bulaşır; kimi zaman mesafeyi kaybeder, ancak belki de bu sayede steril ve dengeli bir metinler topluluğu yerine kışkırtıcı ve kurgusal bir kitap olarak karşımızda durur. Kitabın editörlerinden Sze Tsung Leong (2001, 129), alışverişi insanoğlunu bir araya getirebilen nadir eylemlerden biri olduğunu söyleyecek kadar şehvetle savunur. Leong'a göre, insanlar hayatlarında hiç okula, müzeye, kiliseye ya da hastaneye gitmeyebilir, ama mutlaka bir gün bir yerde alışveriş yaparlar (2001, 129). Alışveriş kaçınılmazdır. Üstelik yapılı çevrede, barınmadan sonra en çok yer kaplayan aktivite alışveriştir (Leong, 2001, 129). Kitapta bu gibi veriler, hatır1 sayılır miktarda ironi ve spekülasyonla harmanlanır ve genel olarak nasıl olup da bunca yıl alışverişin gücünün ve iktidarının görmezden gelindiği sorgulanır. Yine de, bütün bu istatistikler, veriler ya da kitapta bulunabilecek diğer tablolar yeteri kadar ikna edici değilse ve alışverişin "yüksek mimari” ile olan sorunlu ilişkisinin üstesinden gelmek için daha fazlası gerekiyorsa, o da vardır: Kitabın hazırlandığı yıllar, yeni master planının tasarlandı ̆̆ı yıllara denk düşen kent, Almere (Herman, 2001a, 391).

Almere master planı, alışverişin kentlerde yaratabileceği potansiyelin farkına varmış bir ekip tarafından tasarlanır. Ancak kentler, genelde plancıların ve yöneticilerin öngörülerine uygun gelişmez. Almere örneğinde de, kent bir kere daha karar mekanizmalarını yanıltmış, onca çabaya rağmen Almere hayal edilen metropole henüz dönüşememiştir, ama 


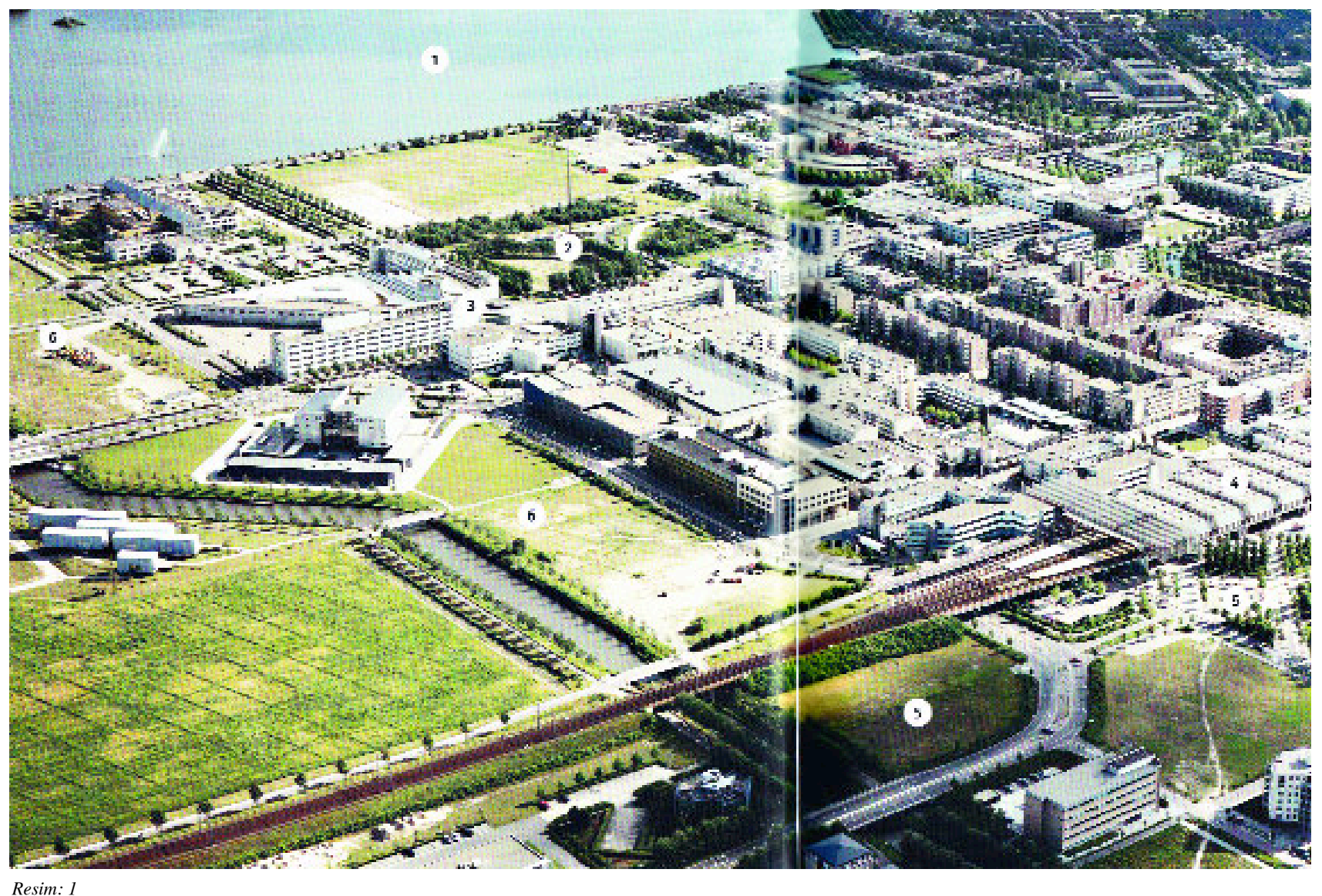

alışveriş ve kentsel tasarım arasındaki ilişkiyi incelemek için iyi bir örnek olarak plancıların önünde durur.

Almere, Hollanda'nın "Polder" olarak adlandırılan, Türkçeye “denizden bozma kara parçası" olarak çevirebileceğimiz bölgelerinden birinde 1976 yılında kurulduğunda nüfusu 45 kişidir. 1994 yılına kadar, tasarımını Teun Koolhaas'ın yaptığ 1 master planın 1zgaraları üzerinde, iddiasız bir Hollanda kenti olarak büyür (Jantzen ve Vetner, 2011, 15). Bahçeli evlerinde yaşayan, boş vakitlerini evlerinde geçiren ve bundan şikayetçi olmayan (Alkemade, 2007, 75) banliyö nüfusu 100.000’e ulaştı̆̆ında, yeni bir master plana ihtiyaç duyulur ve 1994 yılında şehir için bir master plan yarışması açılır. Aslında master plan ihtiyacının altında, hızla artan nüfustan daha etkili bir sebep yatar.
Hükümetin ekonomik kaygıları (Alkemade, 2007, 76) ve Almere'de eksikliğini hissettiği "farklı kimliğgi" oluşturacak bir Şehir Kalbi: "Yeni ve deneysel, herkes için çekici, heterojen bir merkez" (Jantzen, Vetner, 2011, 15). Jantzen ve Vetner'e göre $(2011,16)$, "Almere için büyük atılım" olarak kamuoyuna duyurulan davetli yarışmayı Teun Koolhaas'ın kuzeni Rem Koolhaas ve ekibi OMA kazanır. Neredeyse 20 yıllık geçmişi olan bir kentte yeni bir merkez tasarlamak ve bu yeni merkezin kentin geleceğini tamamen değiştireceği gibi büyük bir beklentinin altından kalkmak zorlu bir iştir; Almere'nin 20'li, Koolhaas'ın 50'li yaşları bu hedefe ulaşma çabası ile geçer. 


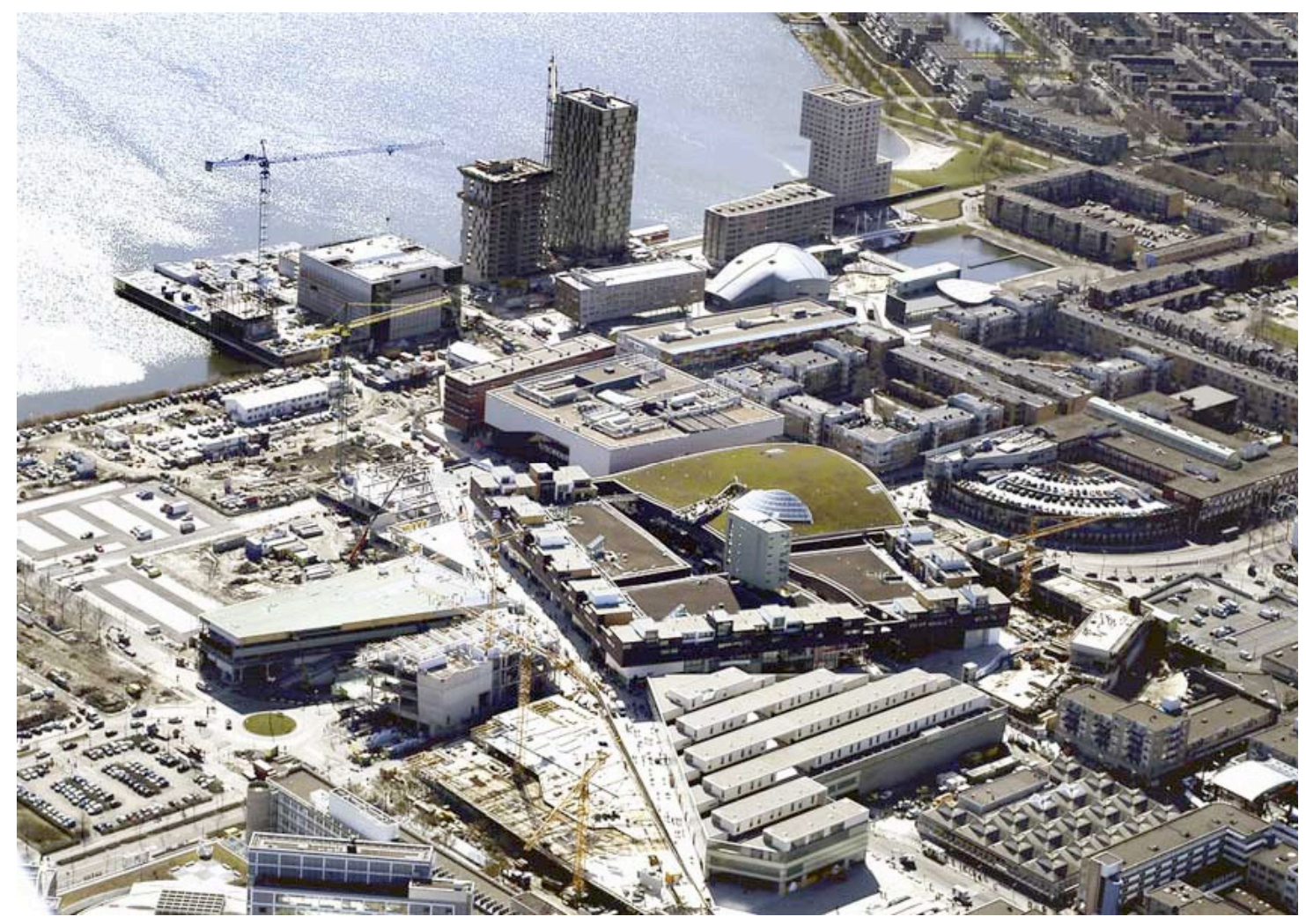

Resim: 2 Bir kentsel kimlik olarak tekdüzelik

2000'lerde Almere, OMA'nin hazırladığı master plan gerçekleştikten sonra.

Floris Alkemade 2008 y1lına kadar
OMA'nın ortaklarından olan Rotterdaml bir mimardır. Yarışmanın açıldığı 1994 yılına kadar, arkadaşlarıyla dışarı çıktığı bir gece yarısı dışında, Amsterdam'a $30 \mathrm{~km}$ mesafedeki Almere'ye yolu hiç düşmemiştir. Bir gece, bira içecek bir yer bulma ümidiyle arabayı Almere'ye doğru sürerler ve içlerinden hiçbiri daha önce Almere'ye gitmediği için neyle karşılaşacaklarını bilmezler. Şehir merkezini ararlar; yapılaşmanın biraz olsun yoğunlaştığı, birkaç dükkanın öbeklenerek kentin geri kalanından farklılaştı̆̆ bulabilmek için şehri baştan sona katederler. Ancak şehir merkezini bulamazlar, Almere'nin merkezi yoktur (Alkemade, 2007, 76).

Sonsuza kadar uzayıp giden, birbirinin aynı, bahçeli evlerden oluşan Almere için Alkemade "Cehennem gibiydi", der (Alkemade, 2007, 78).

Alkemade'nin sıkıc1, sıradan, biteviye taşra yaşantısını tasvir etmek için başvurduğu cehennem benzetmesinin, başka mecralarda sıklıkla yoğun, boğucu, ateşli metropol hayatını anlatmak için de kullanılıyor olması ilgi çekicidir. Ancak cehennem benzetmesini bir kenara bırakırsak, Alkemade'nin Almere hakkındaki ilk izlenimi biraz da kent yöneticilerinin kentin üzerinden atmaya çalıştıkları, kentin 20 yıllık geçmişinde edindiği özelliklerle paraleldir. Kimlik, Almere için şehrin ilk kurulduğu 70'li yıllardan beri üzerinde durulan bir meseledir.

Almere, üzerinde hiçbir kentsel, tarihi ya da politik referans barındırmayan bir “polder"de 70'lerde başlayan varoluş hikayesi ile bir erken dönem Dubai örneği gibiydi: biri kum tanelerinden, diğeri 


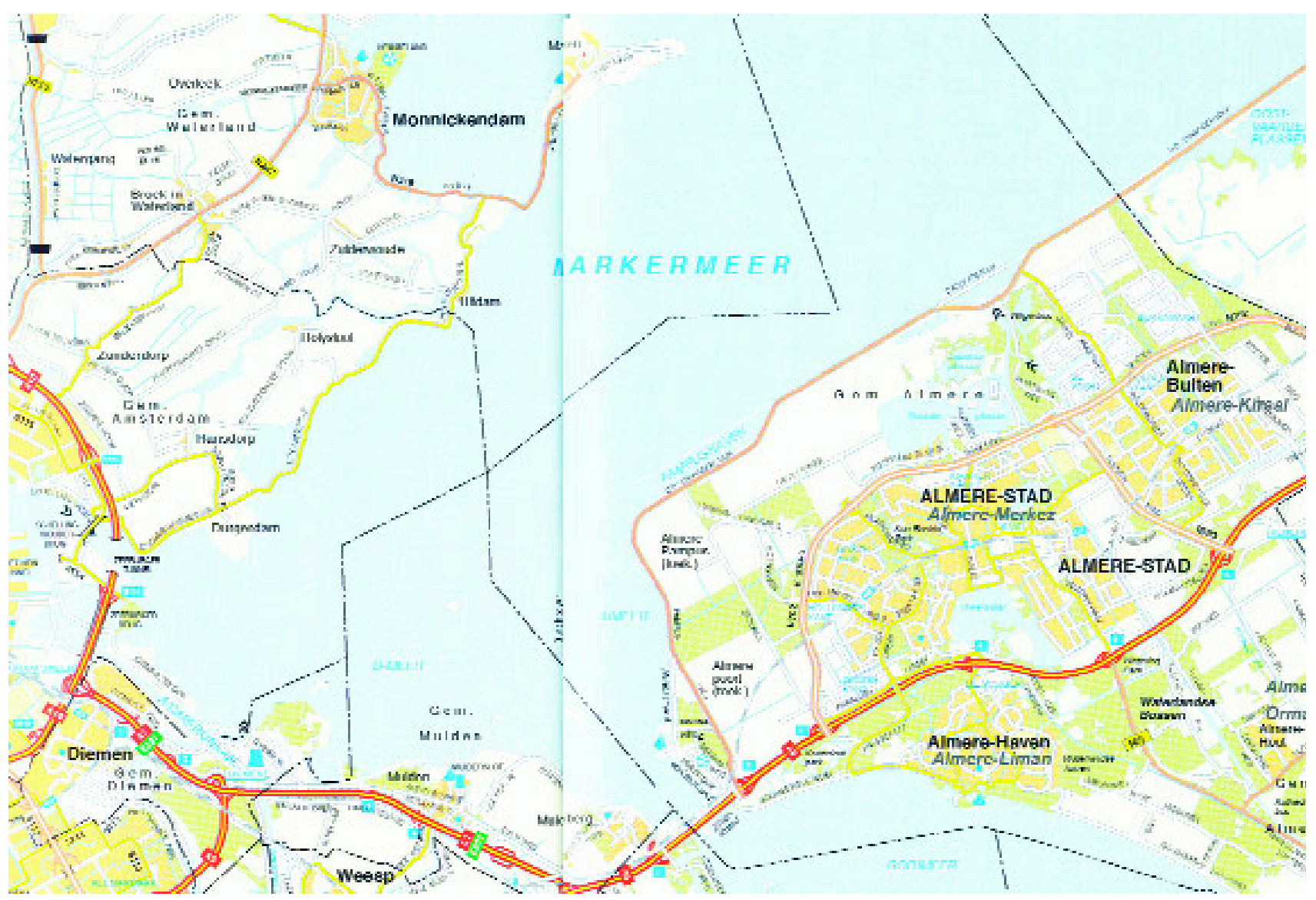

balçıktan oluşan boş beyaz sayfaların üzerine örülen iki şehir. 70'li yıllarda Almere'nin planlanması ile görevli mimar ve plancılar, kenti özellikleri değişen dört bölgeye ayırmıştı ve bu bölgelere verdikleri isimlerle kent kimliği için ilk adımı atmışlardı (Provoost ve Colenbrander, 2000, 18). Bu isimler Almere-Merkez, Almere-Kirsal, Almere-Orman,

Almere-Liman idi.

Her ne kadar bu isimler coğrafi özellikleri yansitıyor gibi görünse de, aslında bu bölgelerdeki kullanıcı tipleri ve onların yaşam biçimleri ile ilgili ipuçları veriyorlard1: Almere-Liman da ortak kullanım alanları olan işçi konutları, Almere-Kırsal'da yerini, bahçe içerisindeki müstakil yapılara bırakıyordu (Proovoost ve Colenbrander, 2000, 22).
Bu kimlik girişimleri Almere şehrini ancak 20 yıl idare edebilmişti; 90’lı yıllarda Almere kimliği tartışmaları yeniden alevlendi.

Koolhaas'ın Almere ile olan bağı master plan yarışmasından çok önce, 1982 yılında şehrin polis merkezi binasını tasarlaması ile başlar; OMA'nın inşa edilmiş ilk yapısı Almere'deki bu yapıdır (Proovoost and Colenbrander, 2000, 26). Bundan 12 y1l sonra Almere merkezinin planlaması için OMA harekete geçtiğinde, ofistekilerin gözünde Almere yalnızca genç ve mutlu ailelerin yaşadığı bir şehirdir: bir türlü "büyük şehir” olamamış Hollanda'nın beşinci büyük şehri (Alkemade, 2000, 35).

Almere'de ne yoksa OMA'nın önerdiği master planda vardır. Almere az katlıdır, 
plan çok katlı. Almere düşüik yoğunlukludur, plan yüksek yoğunluklu. Almere 1zgaradır, plan diagonallerle dolu.

Koolhaas'ın sözleri ile "plan Almere'nin mevcut haline bir saldırıdır" (2004, 12). Ancak burada Koolhaas'ın bilinçli spekülatif üslubuna kapılıp da, yeni master planın bir tabula rasa olduğunu, cüretkar bir girişim olduğunu söylemek anlamlı olmaz. Bunun nedeni de şudur; Almere 20 yıllık geçmişi ve kelimenin tam anlamı ile boş bir sayfa üzerine işlenmiş ızgara planı ile zaten oturmuş ve yıllanmış bir şehir değildir. Burada daha kritik olan, OMA'nın saldırısının yalnızca planometrik kentsel tasarım prensipleri üzerinden mevcut kent tasarımına yapılan bir taarruz olmamasıdır: kentin ön koşulu/ön koşulları kökten değiştirilecektir.

Kentlerin canlılığg için gerekenler her dönemde değişir. McMorrough'ın (2001, 194) HDSGS'deki tespitine göre genel olarak alışveriş uzun zaman önce kentsel bir aktivite olmaktan çıkmış, kentlerin ön koşulu haline gelmiştir. Kentin yegane olmazsa olmazı. Önceleri kent merkezlerine benzetilerek tasarlanan AVM'ler, artık yeni kent merkezleri için birer prototip olmuştur; kent merkezlerinin AVM'ler gibi, güvenli, temiz, kontrol edilebilen yerlere dönüşmesi yerel yönetimlerin rüyasıdır. Kent yöneticileri hayallerini gerçekleştirmek için uğraştıkça, kent merkezleri ile AVM'lerin arasındaki benzerlikler artar ve bu ikisi arasındaki ilişki muğlaklaşır. Herhangi bir kent merkezindeki mevcut dokunun yeterince AVM'leşemeyeceği anlaşılınca da, AVM türlü kılığa girebilen bir komedyen gibi yardıma koşar; kentin ortasında çeşitli uzuvlarına kent parçası süsü verilmiş olarak yerini alır. Bazen çatısı kent meydanına dönüşür, bazen de avlusu kent bahçesine. Almere bu dönüşümü açıkça izleyebileceğimiz örneklerden biri olarak karşımızda durur.

Kente dair mevcut verilerin ideal kent imgesi önünde birer engel olarak görüldüğü, sanki her biri olmayan “polder'ler üzerinde tasarlanmış modernist kent hayallerinin çöküşünü gösteren canlı bir örnek olarak Almere, henüz OMA'nın eli değmemişken de, Amsterdam'ın kıyısında bir banliyö olmaktan kurtulamamıştı. OMA'nın önerisi ise, Almere'nin büyük şehir olabilmesi için alışveriş eylemini bir önkoşul olarak sunuyordu.

HDSGS'nin editörlerinden Leong'un (2001, 129), alışverişisin insanları birbirine bağlayan ender aktivitelerden olduğuna dair olan kanısı, Almere'nin özlem duyduğu (düşünülen) kent yaşamının alışveriş sayesinde ortaya çıkacağı fikrini de destekler. Yarışma şartnamesinde altı çizilen "Almere için yeni bir kentsel kimlik", alışverişin bir araya getireceği insanlar yardımıyla ortaya çıkacaktır.

Kimlik tartışmalarını irdelemek için Alkemade'nin Almere ile ilgili ilk izlenimlerine dönelim. Alkemade bir taraftan kenti tasvir ederken bir taraftan da biteviye bir peyzajın içinde tekrar eden küçük, bahçeli evlerle, cehenneme benzettiği şehrin kimliğini tarif ediyordu: sadece genç ve mutlu ailelerin yaşadı ğ şehri sağlıklı hayvanların üremesi için hazırlanmış bir damızlık merkeze benzetiyordu. Her iki benzetmenin de ortak noktası, hem fiziksel yapı olarak hem de nüfus çeşitliği açısından, bir kentsel kimlik olarak tekdüzelik. Elbette, yarışma şartnamesinde aranan yeni kimlik, tekdüze olamazdi. Almere'nin mevcut halinden duyulan memnuniyetsizlik, Almere'nin yeni kimliğinin nasıl 
olmayacağını belirtiyordu.

Kentlere kimlik giydirme merakının uzun bir tarihi var, ama kentlerde göz alıcı, çarpıcı, farklı ve biricik bir kimlik arayışının, markalaşma ve küresel ölçekte ön plana çıkma hevesi ile beraber kuvvetlendiği söylenebilir. Bütün bunlar, şüphesiz tekdüze olmayı kentlerde aranan bir özellik olmaktan çıkarır. Taşradan metropole giden zorlu yolda, tekdüzelikten acilen kurtulunması gerekir. Almere için istenilen kimlik tanımında da farklılı̆̆ın altı 1srarla çizilir.

OMA'nın Almere için önerdiği yeni merkez 300mx300m boyutlarında bir megastrüktürdür. Zemin kotu tamamen araç trafiğinden arındırılmış, ön cephesi olmayan -aslında bütün cepheleri ön cephe gibi tasarlanmış- yapılardan oluşan, ancak otoban kenarlarında rastlanabilecek büyüklükteki alışveriş hacimlerini içeren bu iri kütle, istenen kent merkezini oluşturacaktır. Kent merkezinin zemin altındaki kotu dev bir otopark olarak düşünülmüştür ve tüm servis ihtiyaçları bu kottan sağlanacaktır. Projenin müelliflerinden Alkemade bu radikal fikri nasıl açıklayacağını düşünürken (Alkemade, 2007, 80), yarışma jürisi yoğunluk yaratma fikrini ve Almere'de olmayan her şeyi içeren yeni bir kimlik önerisi olan bu planı çok sever. Yalnızca 300mx300m boyutlarında tek bir kütle yapmak yerine yapıları parçalamayı önerirler; ancak bu yolla yatırımcıları ikna edebileceklerdir. Kent merkezinin geleceği, yatırımcılara bağlıdır, ancak kent yönetimi bu noktada da tedbiri elden bırakmaz. OMA'nın hazırladı $\breve{g}$ plan bitip inşaat aşamasına geçene kadar, Almere'de ticari aktivite yapılacak gayrimenkul yatırımlarına izin verilmez. Bu kisitlama sayesinde plan

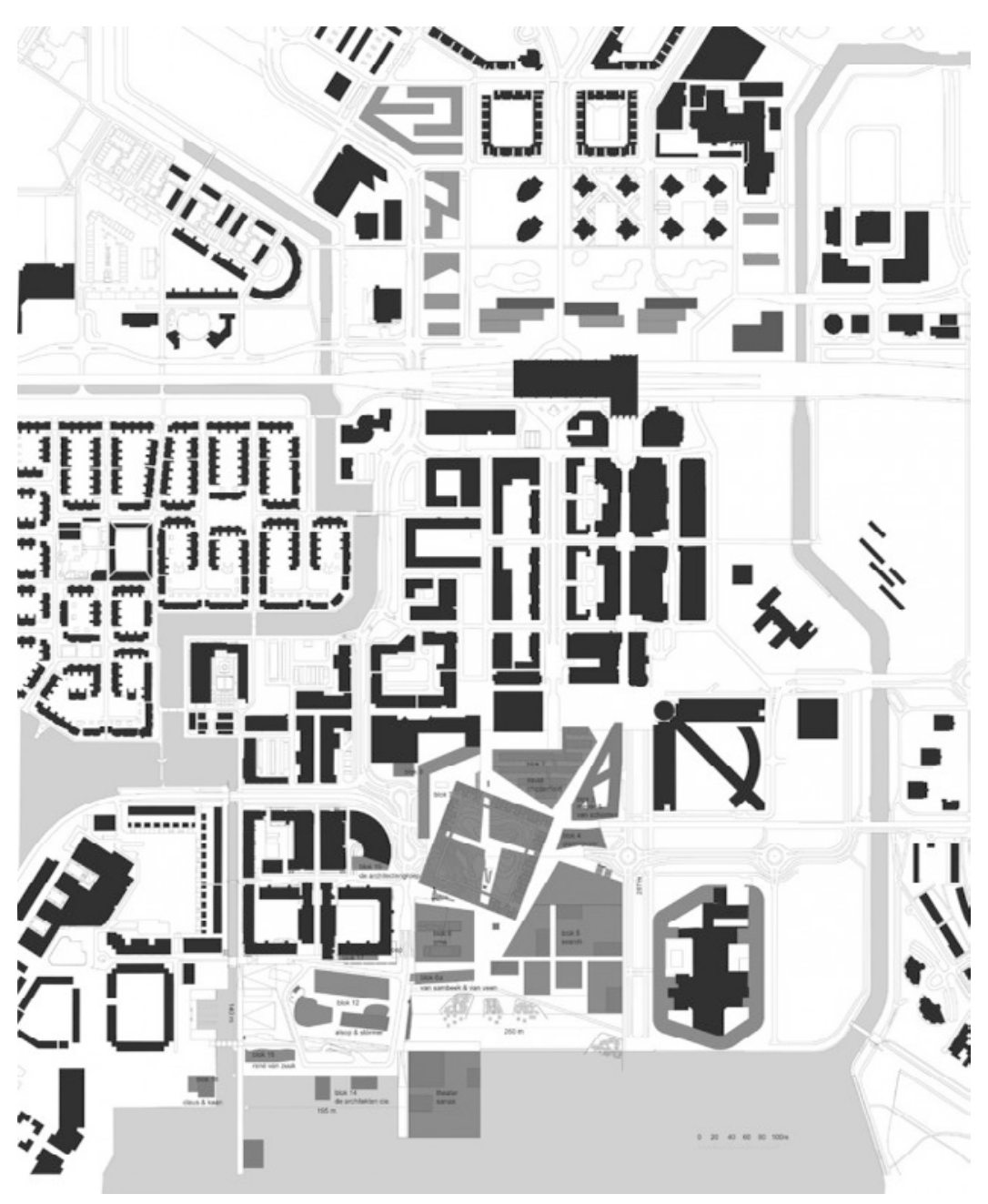

bittiğinde önemli miktarda müşteri hazırdır. Yıllarca bekleyen yatırımcılar, plan biter bitmez davet edilirler

Resim: 4 OMA'nin master plan önerisi
Hollandalı yöneticilerin, her adımı önceden hesaplanmış ve temkinli planlama yaklaşımı, söz konusu olan bir kent tasarımı da olsa işi şansa bırakmamak için ellerinden geleni yapmaları, kusursuz, tam ve işler bir kent ideali arayışının sonucu olabilir. Ekonomik, sosyolojik ya da mimari açıdan karşılaşılabilecek tüm sorunlar incelenir, yeni Almere'nin hayal edildiği gibi hayata geçmesi için ne gerekiyorsa yapilır. 


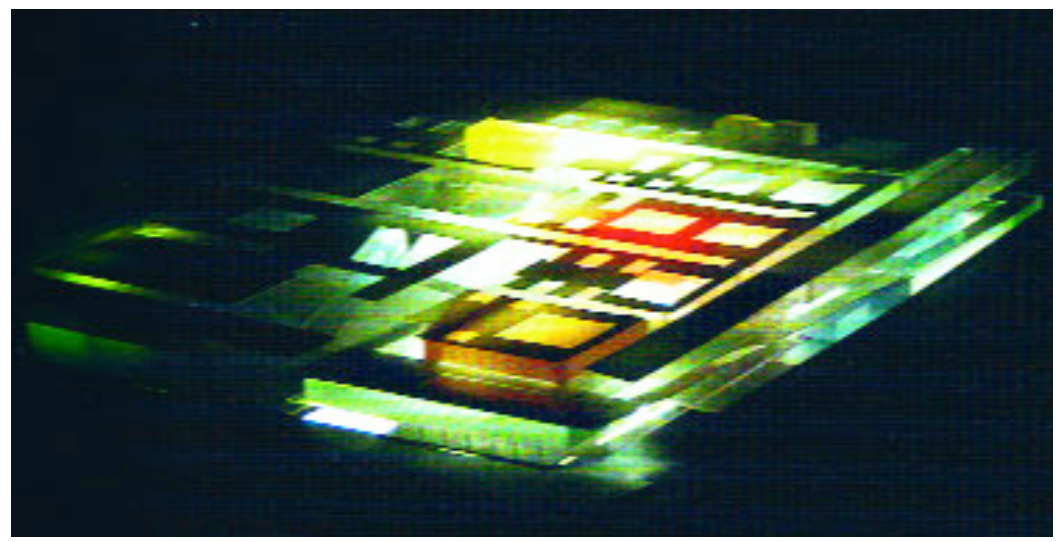

Resim: 5

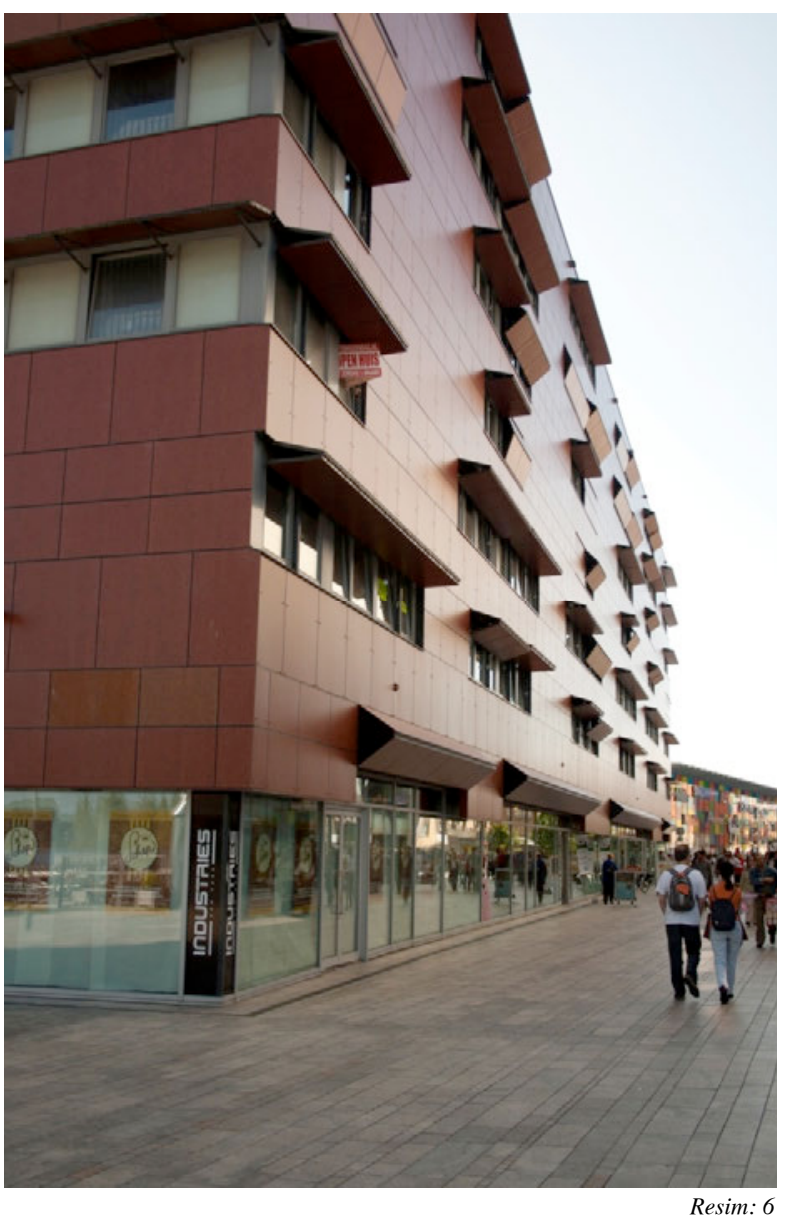

Resim 5: Yarışma şartnamesinde de altı çizilen Yarışmada önerilen $300 \mathrm{~m} \times 300 \mathrm{~m}$ boyutlarındaki kent merkezi tasarımı

Resim 6: Almere kent merkezinde bir yapı, 2009
Almere'nin müstakbel kimliğinin nasıl olacağı tartışmalıdır. Müelliflerden Alkemade 90'ların sonunda, Almere'de yeni planı kamuya aktarmak için yapılan geçici binada ziyaretçileri bilgilendirmekle görevlendirilir. Yeni Almere'yi anlatırken kentin biraz ortaçağ şehirlerine benzediğini söyler (Koper, 1999). İki kotlu plan önerisinde yayalaştırılmış meydanlar ve araç geçmeyen sokaklardan oluşan zemin kurgusunun ortaçağla olan benzerliği ancak kağıt üzerinde geçerli olabilir. Gerçekte Almere, olanca sterilliği, düzeni ve konforu ile ortaçağ şehrine benzemekten çok uzaktır.

Kimlik, genel olarak Koolhaas için netameli bir konudur. Koolhaas açıkça mimarisinde Hollanda'ya ait hiç bir şey bulunamayacağını bir röportajında belirtmiştir (Koolhaas, 2011). Bu beyana dayanarak denilebilir ki, Almere'nin kimliği de Hollandalı olmayacaktır. Çeşitlilik, kimlik tasarımında ve yarışma şartnamesinde hep vurgulanmıştır. Ancak çeşitlilikten kastedilen salt mimari çeşitlilik olsa gerek ki, Almereliler'le 2009 y1lında yapılan bir ankette, "şehirdeki kentsel kalitenin artması için hangisi artmalıdır" sorusunu yalnızca katılımcıların \%10'u nüfus çeşitliliği olarak yanıtlamıştır (Zhou ve Commander, 2009, 308). Halbuki, sadece Hollanda şehirlerinde değil dünyadaki metropollerde açıkça gözlemlenebilir ki, nüfus çeşitliliği kentsel canlılı̆̆ın artmasında önemli bir etkendir. Hollanda'nın hatırı sayılır göçmen nüfusunun kent hayatına katılması, kurtulmak istediği taşra kimliğinin metropole doğru evrilmesini sağlayabilirdi; ancak bu anket Hollandalıların böyle düşünmediğini gösteriyor. Almere ilk kurulduğu yıllarda, şehre yerleşenlerin büyük bir kısmını Amsterdam'daki yoğun göçmen nüfusundan kaçan Hollandalılar'ın oluşturması da bu anketin sonuçlarını destekliyor.

2000'lerin ortasında yeni şeklini almış Almere merkezi ise Building Design 


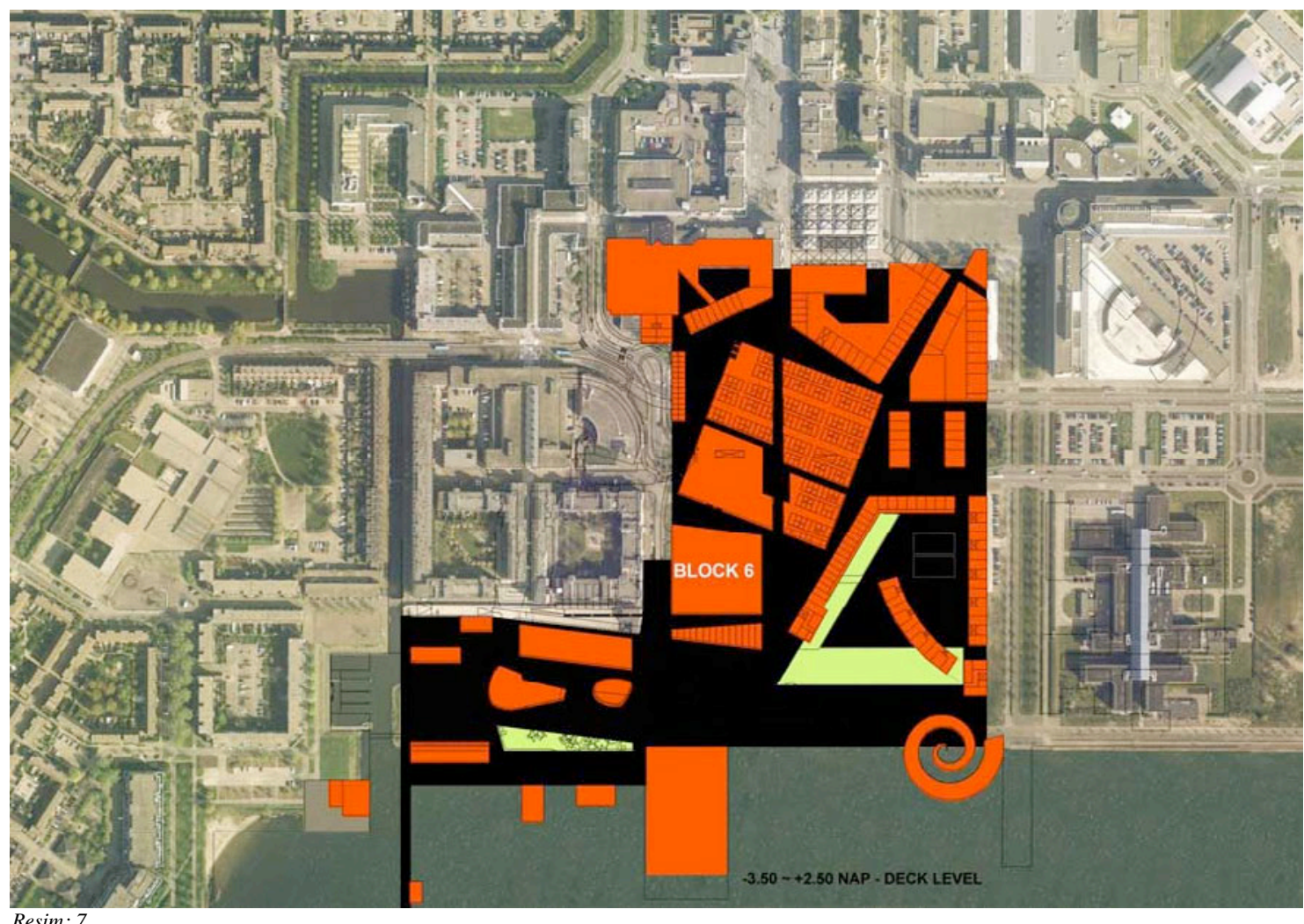

Resim: 7

dergisinde yayımlanan bir makalede, mimari başyapıtların sergilendiği bir hayvanat bahçesine benzetilir (Woodman, 2004).

OMA'nın masterplanı hazırlamaya başlamasından ve uygulanmasindan sonra geçen 10 yılda şehir farklı mecralarda türlü türlü benzetmeyle tasvir edilir; Almere'nin benzeyemediği tek şey büyük şehirdir.

\section{Almere merkezinin araç trafiğinden} arındırılmış sokakları, her köşe başına serpiştirilmiş ünlü mimarların tasarladığı yapıları, karma fonksiyonlu bir merkez olması gibi özellikleri kentin kimliğine dair olmasa da, başlangıçta sözü edilen ideallik arayışına dair izler taşır. İdeal kent, daha fazla insanın daha konforlu koşullarda, müreffeh bir ortamda dilediğince alışveriş yapabilmesi ön koşulu taşır: en azından HDSGS

yazarlarının böyle bir kanıya sahip olduğu bilinir. Almere kent merkezi tasarımında da konfor çok önemlidir; kent merkezinin üzerine kurulduğu alışveriş eylemi ancak yeterli konfor koşulları (geniş ve trafikten arındırılmış yaya yolları, çokça otopark, el altında yeme içme birimleri, olumsuz hava koşullarından korunan açık alanlar) sağlandı ğında artarak şehre yayılabilir. Kesintisiz kumar oynanabilmesi için içerisinde her türlü ihtiyaç ve lüksün bulunabileceği casino'lar gibi, Almere kent merkezi de, alışverişin herhangi bir kesintiye uğramadan yapılabilmesi için gerekli altyapıyı sunar (Resim 7).

Almere'nin neye benzediği değilse de neye benzemediği açıkça söylenebilir: Almere imgesel olarak dev bir açıkhava alışveriş merkezine benzese de, AVM'lerden oluşan bir şehir merkezi olarak tasarlanmamıştır. Bunun nedeni de şudur:
Resim: 7

OMA'nın önerisi ve mevcut kent dokusu Resim: 8 Trafikten arındırılmıs kent merkezi Resim: 9 oMA'nın merkezdeki programatik dağılım önerisi 


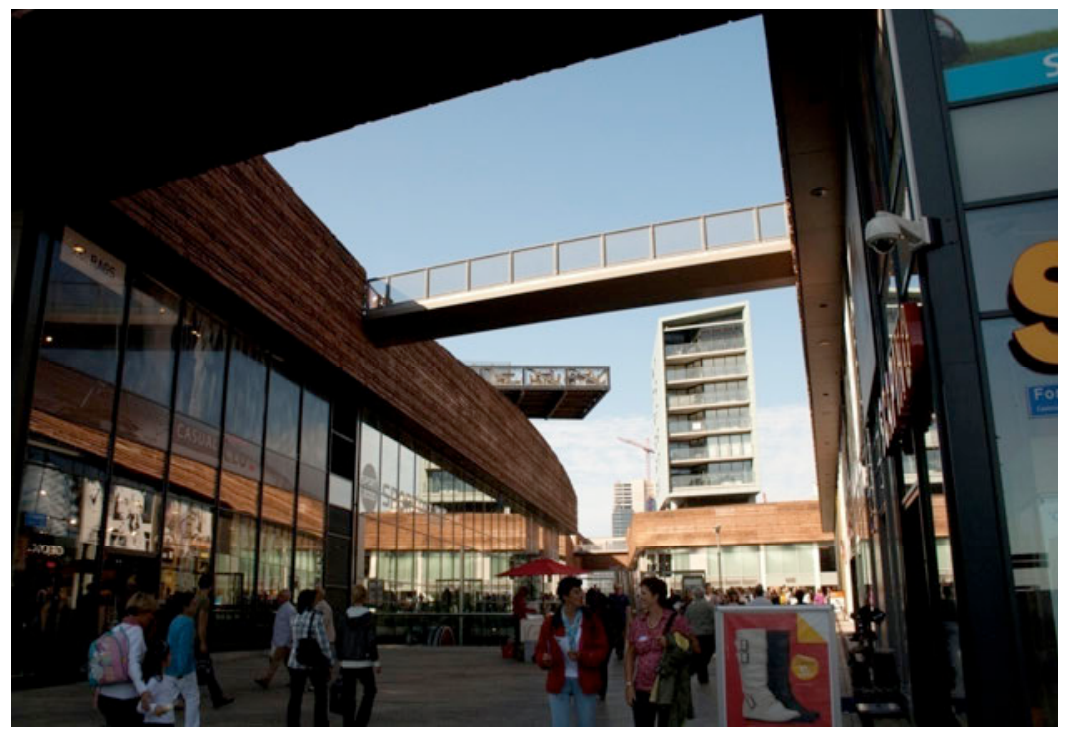

Resim: 8

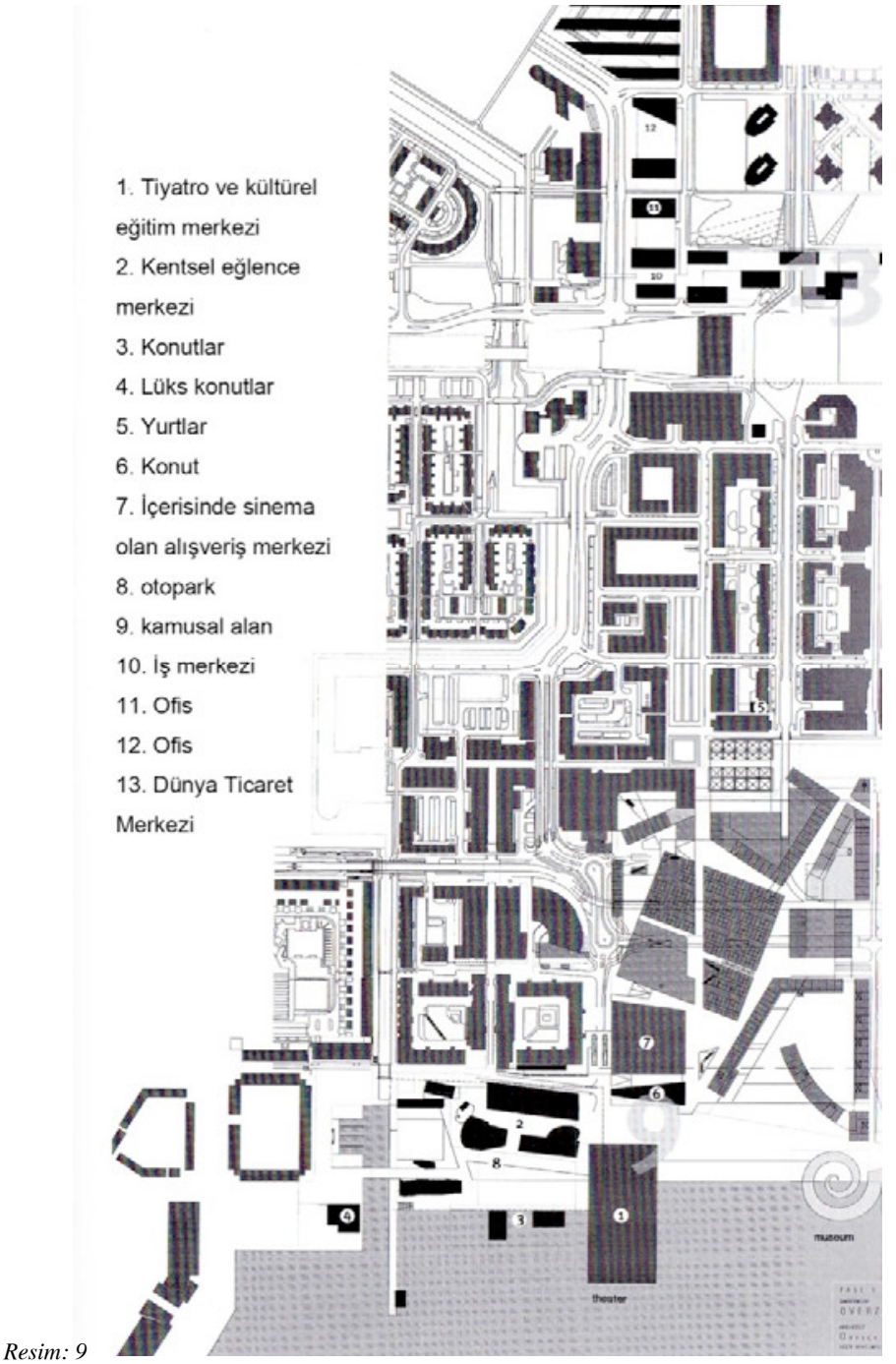

Almere'de alışverişin aldığı biçim, AVM değildir; yeni bir tipolojidir. 21.yüzyılda AVM çoktan ölmüştür. Herman (2001b, 463), HDSGS'de AVM'nin ölümünün altını çizer. Ancak tıpkı 'ölmüş bir dil olan ancak bir çok yeni ifade sisteminin kökünde yatan Latin dili (McMorrough, 2001, 202) gibi, AVM'nin kadavrası da yeni türlerin ayakta kalabilmesi için gerekli veriler içerir. Alışveriş ancak kentin kendisine dönüşürse, AVM'ler kutulara hapsedilmez, sokaklara dökülürse, tabii bir taraftan da AVM'nin sağladığı konfor sağlanabilirse, kentlerdeki boş sokaklar canlanabilir. Tamamen yayalaştırılmış zemin kotundaki dolaşım kurgusunun hedeflerinden biri budur. Almere bir alışveriş kentidir, ancak her büyük şehir gibi kendine has bir alı̧veriş deneyimi sunmalıdır. Bu talebin master plan yarışması süresince ısrarla altı çizilir (Provoost, Colenbrander, 2000, 70), .(Resim 8).

Kent merkezinin tasarımındaki en önemli aktivite olan alışveriş toplam metrekarenin dörtte üçünü kaplar. Ancak alışveriş yalnız mekan tipolojisi olarak değil, bir eylem olarak da evrilmiştir. Denilebilir ki, HDSGS bu evrim üzerine kurulu bir rehberdir. Alışveriş, üniversitelerin, kiliselerin, camilerin, konser salonlarının, kısacası kentteki tüm işlevlerin üzerinden parlak bir cila gibi geçer. Kamusal aktivitelerin yapıldığı bu mekanlar, ya AVM'ye benzemeye başlamıştır, ya da metrekaresinin bir kısmını alışveriş eylemine hibe ederek programatik açıdan dönüşmektedir. Jameson'ın $(2003,68)$ satın almayı gerektirmeyen, parasız da yapılabilecek alışveriş tanımındaki gibi alışverişin dönüştüğü bu yeni hal, HDSGS'de izleri sürülen "alışveriş şehri”" fikrinin ve belki de Almere'nin çıkış noktası olabilir. Master planda önerilen, kütüphane, sonraki aşamalarda 
uygulanacak üniversite gibi işlevlerin yanı sıra müze, konser salonu gibi işlevler de bu kurgunun bir parçası olarak şehirde konumlanır (Resim 9).

Almere kent merkezi, mimarlık turizmi için iştah açıcı olabilecek en az 5-6 yapının 90000 m2 yüzölçümlü küçücük bir kent parçasında bulunabileceği, tasarımda istiap haddini doldurmuş bir kent merkezi olarak 10 yıl içerisinde yeniden inşa edilir.

Hayatta kalıp kalmaması alışverişe bağlı olan bir kentsellik, doğal olarak alışveriş bittiğinde, akşam olup dükkanlar kapandığında yok olma tehlikesiyle karşı karşıya kalır. Aslında mesai saatleri sonrası 1ssızlaşma, yalnızca Almere'nin değil Hollanda'daki ve hatta Avrupa'daki birçok şehrin sorunudur ve bu sorunu çözebilmek için yalnızca kentsel tasarımın yeterli olabileceğini düşünmek anlamlı olmaz. Ancak araç trafiği de olmadığından, hava kararmaya başladığında 1ssızlaşan Almere merkezinin sokakları, gün boyu gezenlerin ardında kalan parlak cips paketleri, sosisli kağıtları, kola kutularından oluşan manzara ile kötü bir "junk space” şakasına dönüşür. Alışveriş bitince kentsellik de biter. Koolhaas'ın (2001, 412), Almere kent merkezi inşaatı bitmeden yazmış olduğu, HDSGS'deki tek metni Junkspace'de kamusal alana dair genel tespiti

Almere'de gerçekleşmiştir: Junkspace'in koridorları gibi, Almere'nin sokakları da A'yı B'ye bağlamak için yapılan mekanlar olmaktan çıkar, varılacak yerin kendisine dönüşür. Sokağı yalnızca iki yanında yapılar olan bir yol olarak, mekansal özellikleri ile tarif etmek özellikle kentsel ölçekteki projelerde mimarların düştüğü, ya da düşmeyi sevdiği bir tuzaktır. Gerçek bir sokağı junkspace'den ayıran özellikler başka bir makalenin konusu, ancak

$56 \mid$ sayı 14, 2012 denilebilir ki, Almere kent merkezinin "tutmamasının" sebeplerini aramaya sokaklarından başlanabilir.

Herhangi bir kamusal mekanı kağıt üzerinde tasarlamak ve o tasarımı kentte uygulamak, orada kamusal yaşam olacağını garanti etmez; ancak böyle bir tereddüt ve şüpheye sahip olsa bile, genellikle tasarımcılar bu durumu saklamayı tercih ederler. Koolhaas (2004), 2000'lerdeki vaktinin önemli bir kısmını kaplayan Almere için "paralel yaşamım” der. Junkspace metni ise, yazılış amacının öyle olup olmadığını bilmesek de, sanki Almere için yazılmış bir kehanet gibidir; Koolhaas'ın kamusallığa dair tereddüt ve şüphelerini de içeren.

\section{Şöhret mi, saygınlık mı?}

Koolhaas, bir sergisinde 1960'larda çekilmiş bir fotoğrafı gösterir. Fotoğrafta bir mimar, rüzgarlı bir şantiye sahasında elinde çizimlerle, inşa edilmekte olan bir sosyal konut projesinin tam ortasinda durur. Koolhaas, resimdeki mimarın yerinde olmak ister (Heathcote, 2011). 2011 yılında Financial Times'da yayınlanan bir söyleşisinde mimarlığın özel sektör tarafından ele geçirilmesinden yakınır, kendisinin mesleğe başladığı yıllarda "mimar kamuya hizmet eder" kanısı hala geçerlidir. Mimarların şöhreti arttıkça daha az ciddiye alındı ̆̆ını söyleyen Koolhaas (2001, 415), Junkspace metninde de mimarinin 20. yüzyılda ortadan kaybolduğunu düşünür ve ekler: "şimdi biz elimizde kalan bir dipnotu mikroskop altına tutarak, onun bir romana dönüşmesini ümit ediyoruz”.

Jameson (2003, 69), Koolhaas'1n HDSGS

kitabındaki rolünü "tanrısallığın bazı biçimleri gibi, aynı anda hem hiçbir yerde hem her yerde" diyerek betimler. HDSGS'deki çoğu 
makaledeki alışveriş̧e geç de olsa hakkını teslim eden coşkulu tavrın aksine,

Koolhaas'ın metni, alışverişin kaçınılmaz iktidarı karşısında zorunlu ama yine de soğukkanlı bir kabulleniş olarak da okunabilir. Üstelik Koolhaas (2001, 420), kendi kendini uyarırcasına "iç mekanla başlar ama Junkspace bir şehri külliyen yutabilir" demeyi de ihmal etmez. Ağıdan tek seferde dökülmüşçesine yazılmış, HDSGS kitabının tam ortasında yer alan bu metinle, birdenbire kameraya dönüp seyirciyle konuşmaya başlayan oyuncu gibidir Koolhaas. Hastasına bütün olası komplikasyonları açıkça anlatan bir doktorun soğukkanlılığıyla okura Junkspace'i tasvir eder.

Junkspace, “yüksek mimari”nin alışverişle kuracağı açık, net ve dürüst ilişkinin bedelidir.

Almere merkezi ise OMA'nın alışveriş ile yaşamsal bir bağ kurarak tasarladıklarını açıkça kabullenip, ortaya serdikleri bir kent parçası.

2004 yılında, artık yeni Almere merkezi gitgide serpilirken, Koolhaas açıkça öz eleştiri yapar.

Heterojenlik de dogmaya dönüşme tehlikesi içerir ve Almere'deki gibi, çeşitliliğin peşinden koştukça, bir süre sonra farklı olmak üzere tasarlanan her şeyin birbirine benzemeye başladığını, daha homojen olanın ayırt edicileşmeye başladığını söyler (Woodman, 2004). Yola çıkarken hedefin tekdüzelikten kaçmak olduğu Almere kent merkezinin tasarımında, farklılığın bile ekdüzeleşebildiği bir noktaya gelinir.

Tekdüzelik, adeta Almere'nin genetik, değişmez özelliklerinden biriymişçesine, şehirde ne olursa ona sirayet eder.

\section{Kentin ölümü}

“Büyük mă̆aza, flâneur'ün son numarasıdır.”

Walter Benjamin

Alışverişin kent hayatını canlandırdığ yadsınamaz bir gerçek. Mimarinin alışverişle kuracağı dengeli bir ilişki kentleşme için de yararlı olacaktır. Örneğin, Benjamin (2003, 131), bu ilişkinin pasajlarla kurulabildiğini düşünür; pasajlar yapılmasaydı flâneur gibi dolaşmanın önem kazanmasının çok zor olacağını söyler. 1852 tarihli Paris gezi rehberindeki pasaj1 "kendi başına bir kent, küçük bir dünya" olarak tasvir eden satırlarla bu varsayımını destekler. Flâneur gibi dolaşabiliyor olmanın da, modern kentin temel özelliği olmasa da, bir "canlılık" göstergesi olduğu, ya da en azından başka kamusallıklara imkan vereceği söylenebilir. Peki, nasıl olur da bir alışveriş mekanı olarak pasajlar bir tür kentsel yaşam üreteci olarak görülebilirken; bir mimarlık tipolojileri höyüğü olan, kazılsa içinde pazar yerlerine, pasajlara ve büyük mağazalara dair onlarca özellik bulunabilecek AVM'den evrilerek oluşan Almere, bir türlü arzu edilen "canlı" ve "gerçek" kentsel yaşama sahip olamaz?

Almere'nin "gerçek bir kent" olması için nelere ihtiyaç duyduğu sorusu 2007 yılında bir söyleşide Floris Alkemade (2007, 76)'ye sorulduğunda cevabı nettir . Ticari olmayan fonksiyonlar, örneğin bir üniversite- ki HDSGS'de üniversitelerin de hızla AVM'leştiğine dair veriler bulunabilir (Leong, 2001, 137). Master planda, yönetimin şehir dişına alma 1srarlarına rağmen merkezde tuttukları mevcut hastanenin büyümesi de Alkemade'nin diğer önerisidir $(2007,76)$. Almere'deki kentsel yaşamın varlığ1, yalnızca kentsel tasarıma ve dolayısıyla Koolhaas ve ekibinin kararlarına bağlı değildir. Ancak yine HDSGS'de karşımıza 
çıkan "en sonunda alışverişten başka yapacak bir şeyimizin” kalmayacağ 1 (Leong, 2001, 135) varsayımının -ya da temennisinin- ve salt alışverişin kentlere hayat öpücüğü verebileceğinin, en azından kentsel tasarımda çok işlerliği olmadığı Almere örneğinde aşikar. Kentselliğin yok olması, kentin ölümü-canlılığ 1 gibi başlıklar, bu vaatlerin Türkiye'deki deprem korkusu gibi, zaten planlanan inşaat faaliyetlerini meşrulaştırmak için kullanılıyor olma olasılı ğını akla getiriyor. Almere'de ortaya çıkan sonuç, kent yaşamını canlandırmak için niyet ve tasarımın yeterli olmadığını gösteriyor. Ancak bu yetersizliğin nedenlerini irdelemek için bu konuda yapılmış kapsamlı ve çok disiplinli araştırmalara ihtiyaç var. Bu makale kapsamında, söylenebilir ki, 35 yıllık geçmişi ile Almere, Hollanda'da orta ölçekli kentsel planlamadan çok daha fazlasını içeren bir hikaye sunuyor; 21. yüzyılda dünyanın herhangi bir yerinde planlanan bir kentin karşılaşabileceklerini anlatan bir hikaye.

Belki de Koolhaas'ın ve OMA'nın şansı (ya da şanssizlı $\breve{g}$ ) kente ait radikal fikirlerini görece küçük ölçekte de olsa

gerçekleştirme olanağı bulmuş olmalarıdır. Almere kent merkezinde, Corbusier'in, Fuller'in ya da Metabolistler'in kentsel manifestoları ve önerilerinden farklı olarak, karşımızda daha önce denenmemiş, avangard fikirlerin kentte karşılık bulmuş, yatırımcı ve yerel yönetimle müzakere edilerek inşa edilmiş halleri durur. OMA'nın cisimleşmiş önerisi, Almere'nin kentsel yaşamını hayal edildiği kadar etkilememiş, bir planlama başarısı olarak tarihe geçmemiş olabilir, ancak kendinden sonraki nesiller için ufuk açıcılığı ve içerdiği tartışma potansiyeli açısından önemlidir.

$58 \mid$ Sayı 14, 2012
Bir kentsel aktivite olarak alışveriş, ister bir pazar yerinde olsun, isterse bir pasajda, 1ssızlaşan kent merkezleri için bir çıkış yolu olarak görülebilir. Ancak alışverişi ve tüketimi yegane kurtarıcı olarak görmek ya da yalnızca bu eylemlerin kentsellik üretmeye yeteceğine inanmak, bizleri, eğer varsa "gerçek kent" formülünden uzaklaştırıyor. Üniversitelerin, müzelerin, kiliselerin, bir başka deyişle her türlü kamusal alanın tüketim eyleminden nasibini aldığı tespiti doğru olabilir, ancak bu tespiti kentsel tasarımın bir ön koşulu haline getirmek, kentselliği yalnızca ve doğrudan alışverişe bağımlı kılmak da, kamusal alan tanımını dar bir çerçeveye sıkıştırmayı gerektiriyor. Bir taraftan AVM'ler dünyanın farklı köşelerinde hızla inşa edilirken, öte yandan pek çok şehirde, alışverişin can damarı olmadığı kamusal alanlar ve kentler var olmayı sürdürüyor. "Gerçek kent" diyerek altı çizilen imge, tek tip, gereklilikleri tanımlanabilen, nitelik ve nicelik olarak sınırları belli olan bir yapı değil ve gücünü de bu çeşitlilikten alıyor. Kentler için sıkça yapılan laboratuvar benzetmesi ve üniversitelerin sonu -Lab la biten kent araştırma birimleri olduğu sürece "gerçek kent”in de bir formülüi olabileceği kanısı varlığını sürdürebilir. Ancak, Almere gibi uygulamalar da kent ve laboratuvar benzetmesinin çok da geçerli olmadığını gözler önüne seriyor. Teorik olarak, işlerliğini sağlamak için elden ne geliyorsa yapılmış, ancak yine de boş sokaklardan kurtulamamış Almere, kentlerdeki deneylerin sonuçlarının tam olarak öngörülemediği bir örnek olabilir. Hollanda'ya ait hiçbir şeyin mimarisinde bulunamayacağını söyleyen Koolhaas sonunda, Dutchtown Almere adlı bir kitaba adını veren bir kent merkezi tasarlamıştır. 2000 yılında henüz yeni kent merkezinin inşaatı bitmeden yayımlanan 
IVladimir Nabokov, Edebiyat

Dersleri, Ada Yayıları, s.II

II-Project on the City 2, Harvard Design School Guide to Shopping, ed. Koolhaas, R., Chuihua J., Inaba, J., Leong, S., 192-204. Spain: Taschen.

III-Daniel Herman, High

Architecture basslıklı makalesinde

mimarlık ve alışveris iliş̧isinde bir

türlü dikiş tutturulamadığından

bahseder. Yüksek mimarlığın önce

alışverişi tümden reddettiğini sonra

da körü körüne kabul ettiğini ve bu

tuhaf iliski biçiminin kentin aleyhine

olduğunu düşünür. OMA'nın

Almere'deki yaklaşımı bu açıdan

bakınca daha tutarlıdır; açıkça

alışveriş üzerine bir şehir merkezi

tasarladıklarını kabul etmek. HDSGS

gibi bir kitabın varlığı da bu kabul-

lenișin Herman'ın altını çizdiği gibi

"körü körüne" olmadığını

gösterir.

IIII-Bkz. Tdk güncel sözlük

IIIII-Junkspace, bazı kaynaklarda

Türkşe'ye "döküntü uzam" olarak

ceurilmiș, ancak yeterince açıklayıcı

bulmadığımdan bu makale içinde

sözcüğ̈̈n ingilizcesi kullanılmıstır. bu kitap, 30 yıllık kimlik tartışmalarının nihai yanıtıdır: Almere, Hollandalı'dır. O kadar tartışmanın, araştırmanın ve önerinin sonunda bulunan kimlik ve kitabın kendisi yine farkında olmadan bir kehaneti içerir: 2010 yılında herşeye rağmen büyük ve gerçek bir şehir olamamış Almere ve Hollandalı olan herşeyden ne kadar kaçarsa kaçsın, bu Hollandalı kenti tasarlayan OMA.

Almere'de, star mimarların şaheserleri arasında dolaşmak, bir film setini gezmeye benziyor. Yapılar, gerçeğini görünce hayal kırıklığı yaşatan ünlüler gibi. Alışverişin bu yalnız ve birbirinden kopuk yapıları birarada tutacağı ve canlı bir kent oluşturacağı öngörüsü görüldüğü kadarıyla henüz gerçekleşmemiş. Kentlerde kamusal alanların nasıl şekillendiğine dair çarpıcı bir örnek olan Almere merkezinin sokaklarında gezerken Rem Koolhaas'ın 60'larda sosyal konut şantiyesindeki mimara neden öykündüğü belki biraz anlaşılabilir. Bir kent merkezi tasarlamıştır, bundan daha kamusal ne olabilir? Peki, 2000'lerde inşa edilmiş bir kent merkezi, 60'larda inşa edilmiş sosyal konuttan daha az kamusal bir mekan midır? Koolhaas'a ve Almere'ye bakılırsa, öyle. Koolhaas'ınki daha mütevazi ama itibarlı olmaya dair romantik, nostaljik bir istek midir? Yoksa hayati, herkesin ihtiyaç duyduğu bir mimarlık üretiminin öznesi olma arzusu mu? Ya da tanrısallık talebi mi, bilemeyiz. Smithsonian Magazine dergisinde yayımlanan bir röportajında (Ourroussof, 2012), şimdilerde Koolhaas'ın kırsal ile ilgili bir kitap üzerinde çalıştı̆̆ını öğreniyoruz. Koolhaas'ın metropolden ümidi kesmesinde Almere deneyiminin etkisi var mı, bunu da bilmiyoruz. Bildiğimiz, mimarların, yerel yönetimlerin, ya da müteahhitlerin kenti şekillendirirken kontrol edemedikleri bilinmezlerin sonunun gelmediği. Almere, Dubai ve benzeri örnekler bir yanda kağıt üzerindeki hayallerin birebir uygulandığı şehirler olarak karşımızda dururken, öte yanda içlerinde barındırdıkları çelişkilerle ve hikayelerle her şeye rağmen kentin ölmediğini, devinerek yaşadığını hatırlatiyor 


\section{KAYNAKÇA}

Benjamin, W., 2007. Pasajlar. YKY: İstanbul. Davidson, J., 2011. 45 minutes with Rem Koolhaas. [çevrimiçi]. Erişim yeri:

http://nymag.com/news/intelligencer/encounter/rem-kool haas-2011-10/ [Erişim tarihi: 10 Ocak 2012].

Herman, Daniel. 2001a. High Architecture. Project on the City 2, Harvard Design School Guide to Shopping, ed. Koolhaas, R., Chuihua J., Inaba, J., Leong, S., 390-402. Spain: Taschen.

Herman, Daniel. 2001b. Mall. Project on the City 2, Harvard Design School Guide to Shopping, ed. Koolhaas, R., Chuihua J., Inaba, J., Leong, S., 460-476. Spain: Taschen.

Herman, Daniel. 2001c. Three-Ring Circus; or, The Double Life of the Shopping Architect. Project on the City 2, Harvard Design School Guide to Shopping, ed. Koolhaas, R., Chuihua J., Inaba, J., Leong, S., 737-749. Spain: Taschen.

Heathcote, E., 2011. Lunch with Rem Koolhaas. [çevrimiçi]. Erişim yeri:

http://www.ft.com/intl/cms/s/2/e29e2c94-19e0-11e0-b92100144feab49a.html\#axzz1qaVgQHba [Erişim tarihi: 20 Şubat 2012]

Jameson, F., 2003. Future City. New Left Review 21 (1), s. 65-79.

Jantzen C., Vetner M., 2009. Re-inventing Città Ideale Designing Urban Experiences in Almere, [çevrimiçi]. Erişim yeri:

http://vbn.aau.dk/files/16104490/CJMV_Almere.pdf [Erișim tarihi: 15 Ocak 2012].

Koolhaas, Rem. 2001. Junkspace. Project on the City 2, Harvard Design School Guide to Shopping, ed. Koolhaas, R., Chuihua J., Inaba, J., Leong, S. 408-422. Spain: Taschen.

Koper, A., 1999. Almere will go into the sky, [çevrimiçi]. Erişim yeri: http://www.geog.nau.edu/tg/con tents/v1/almere.html [Erişim tarihi, 12 Aralık 2012]

McMorrough, John. 2001. City of Shopping. Project on the City 2, Harvard Design School Guide to Shopping, ed. Koolhaas, R., Chuihua J., Inaba, J., Leong, S., 192-204. Spain: Taschen.

Nabokov, V., 1989. Edebiyat Dersleri. Ada Yayınlar1: İstanbul.

Ouroussoff, N., 2012. Why is Rem Koolhaas the World's Most Controversial Architect? [çevrimiçi]. Erişim yeri: http://www.smithsoni

anmag.com/arts-culture/Why-is-Rem-Koolhaasthe-Worlds-Most-Controversial-Architect-

165593696.html\#ixzz27ywYotc3 [Erișim tarihi, 10 Eylül

2012

Provoost, Colenbrander, 2000. Dutchtown. Dutchtown Almere, ed. Provoost, 13-98. Rotterdam: NAI Publisher.

Ramo, B., Upmeyer B., 2007. Dumped in Almere, 2nd Rate Urbanism Interview with Floris Alkemade. Monu Magazine 7 (1), s. 74-86.

Tsung Leong, Sze. 2001. And Then There was Shopping. Project on the City 2, Harvard Design School Guide to Shopping, ed. Koolhaas, R., Chuihua J., Inaba, J., Leong, S., 128-156. Spain: Taschen.
Woodman, Ellis. 2004. Master Planning: Growing Pains. Building Design 12 (1),

http://search.proquest.com/docview/274588798 accountid $=11638$

Zhou, J., Commandeur, S., 2009. Urban Culture in New Town Almere [çevrimiçi]. Erişim yeri: http://newurbanquestion.ifou.org/proceed ings/3\%20The $\% 20$ Urbanized $\% 20$ Society/full $\% 20$ papers/B0

1_ZHOU_JING_URBAN\%20CULTURE\%20IN\%20NEW\% 20TOWN\%20ALMERE.pdf [Erişim tarihi, 21Mart 2012].

Görseller:

Res. 1 Dutchtown Almere, 2000, NAI Publisher, s.42-43.

Res 2. http://www.e architect.co.uk/images /jpgs/holland/almere_masterplan_oma180809_2.jpg

Res. 3 Dutchtown Almere, 2000, NAI Publisher, s.6-7.

Res. 4 http://st-ar.nl/dumped-in-almere-interview-with-florisalkemade/ (OMA Arşivi)

Res. 5 http://st-ar.nl/wp-content/uploads/STAR_Floris-

Alkemade_03-760x518.jpg (OMA Arşivi)

Res. 6 SO? Arșivi

Res. 7 http://www.e-

architect.co.uk/images/jpgs/holland/almere_masterplan_oma 180809_4.jpg

Res. 8 SO? Arsivi

Res. 9 Dutchtown Almere, 2000, NAI Publisher, s.102 